\title{
Recent developments in the Norms of the Byelorussian Lilerary Language
}

\author{
BY \\ P. J. MAYO
}

I

The development of the Byelorussian literary language over the last fifty years shows a persistent trend from the relative freedom (some might say anarchy) of the 1920s and early 1930s to a detailed concern with the 'culture of language' (kultura movy) exemplified in such publications as the recent Sučasnaja biełaruskaja mova whose foreword opens with the statement that 'The strict unity of lexical, grammatical and phonetic norms, the correctness, purity and expressiveness of the literary language in its written and oral forms are the essential conditions for it to fulfil its function of relations between people most fully and effectively. Every deviation from unified norms, every inaccuracy complicate mutual comprehension and obscure or even completely distort the sense of an utterance. ${ }^{1}$

In the 1920s and early 1930s (and in Western Byelorussia until the outbreak of the Second World War) grammarians concerned with the establishment of literary norms favoured much rural dialectal material, especially forms emanating from the West Central dialects, and the preservation of some archaic material. Russisms and Polonisms were to be avoided; instead neologisms were to be coined on the basis of native or international models. ${ }^{2}$ Within this general framework, however, there was considerable disagreement as to exactly which forms should constitute the literary norm and certainly no really co-ordinated attempt to produce a normative grammar. Even B. Taraškievič, whose pioneering work Biełaruskaja hramatyka dla škot first appeared in 1918, was forced to admit in the preface to the fifth edition, published in 1929, that although various critics had suggested possible improvements and corrections and although he himself could see the need for and possibility of a number of reforms, particularly in the sphere of orthography, he was unwilling to introduce them at present because in isolation such changes for the better could stand in the way of good reform. He considered that the reform of the orthography must be carried out as a whole and in conjunction with a reappraisal of the morphology. ${ }^{3}$

This close link between orthographical and grammatical reform was a theme which was echoed in the 1930s first of all by the plan

1. Sučasnaja bietaruskaja mova, Minsk, 1973, p. 3.

2. P. N. Wexler, Purism and Language: A Study in Modern Ukrainian and Byelorussian Nationalism (1840-1967), Bloomington, 1974, pp. 310-1.

3. B. Taraškievič, Biełaruskaja hramatyka dla škol, fifth edition, Vilna, 1929. 
for a new Byelorussian orthography ${ }^{4}$ (for instance pp. 26-27 set out rules for the use of the endings $-a$ and $-u$ in the genitive singular of masculine nouns of the second declension; on pp. 29-30 recommendations are made for the endings of the second person plural of the present/future tense and imperative mood of verbs) and then in 1933 by the spelling reform itself, albeit in a more restricted way. ${ }^{5} \mathrm{Just}$ as earlier Taraškievič's orthographical reform had provided the impetus for grammatical reform, since the two were often interconnected, so in the period from 1933 to the beginning of the Second World War there appeared a number of authoritative grammars and textbooks incorporating the principles laid down by the 1933 spelling reform. ${ }^{6}$ At the same time these textbooks, which were intended primarily for use in schools and higher educational establishments, were characterised by a wealth of detailed examination of grammatical questions, in particular questions of morphology. Although in many instances the grammars of this period tolerated alternative declensional endings they nevertheless attempted to categorise the spheres of usage of the latter, sometimes introducing changes in the norms established earlier, in the 1920s. Thus, for example, for the instrumental singular of feminine nouns with a stem ending in a consonant (third declension) Taraškievič had considered the ending -ой(-ёй, -ай) as predominant, ${ }^{\top}$ whereas in the 1936 Bietaruskaja hramatyka. Marfatohija the authors regard the original ending of this declension -ью (ко́сцю, мы'шшу, кро́ўю) as the norm, while acknowledging -ой(ёй, -ай) as a literary variant in a few instances (e.g. гра́ззю/гразёй).

In other respects the grammars of 1935 and 1936 were less convincing. In particular they failed to make a proper distinction between the literary language and the language of works of literature, with the result that their recommendations on, for example, the genitive plural ending of feminine nouns of the first declension (e.g. бур/бу́раў) or the instrumental plural ending (е.g. сляза́мі/слязьмі́, пляча́мі/плячы'ма) included as the literary norm a number of variants whose sphere of usage was confined to the language of works of literature. This provoked considerable discussion, most notably in Zviazda and Sovetskaja Belorussija in the years $1938-9,{ }^{8}$ but the

4. Bielaruski pravapis (prajekt), AN BSSR, 1930.

5. Ab źmienach i spraščeñni bietaruskaha pravapisu, Pastanova Savieta Narodnych Kamisaraŭ BSSR, 1933.

6. T. P. Łamcioŭ, Bietaruskaja hramatyka. Fanietyka i pravapis, Minsk, 1935; Bielaruskaja hramatyka. Marfalohija (ed. T. P. Eamcioŭ), Minsk, 1936; Sintaksis biełaruskaj movy (ed. J. Kolas, K. Hurski, H. Sklar), Minsk, 1939; K. I. Hurski, T. P. Eamcioŭ, T. Z. Sklar, S. L. Rochkind, Kurs sučasnaj biełaruskaj movy. Fanietyka. Marfatohija. Leksika, Minsk, 1941.

7. Taraškievič, op. cit., p. 82.

8. See, for example, K. Hurski, 'Ab biełaruskim pravapisie', Źviazda, 9 April 1938; P. F. Chadarenka, 'Patrebna nieadkładnaje spraščeńnie biełaruskaha pravapisu', Źviazda, 6 July 1938; P. Dzik, 'Da pytańnia ab sučasnaj biełaruskaj arfahrafii', Źviazda, 16 Oct. 1938; V. Borisenko, 'O proekte reformy belorusskogo pravopisanija', Sovetskaja Belorussija, 16 Feb. 1939; A. K. Bondarenko, 'Nabolevšije voprosy belorusskogo pravopisanija', Sovetskaja Belorussija, 9 April 1939; 'O reforme belorusskogo pravopisanija (obzor pisem)', Sovetskaja Belorussija, 3 June 1939. 
Kurs sučasnaj biełaruskaj movy published in 1941 showed no concessions to the arguments advanced.

The immediate post-war period to the middle 1950 s was characterised by orientation of the Byelorussian literary language towards Russian. The effects of this were to be seen in all aspects of the language to a greater or lesser extent but perhaps most clearly in lexis. Linguists now began to favour dialectal forms from the East Central dialects and material shared by Russian; there was a reaction against the coining of neologisms and a corresponding tendency to introduce Russisms and international words, especially if the latter were shared by Russian. In the colloquial language too there was a shift from rural to urban norms which would seem to imply, as Wexler suggests, a preference for the Russianised speech of bilingual city-dwellers. ${ }^{9}$ After the publication in 1950 of Stalin's Marksizm i voprosy jazykoznanija books and articles devoted to the Byelorussian literary language (like other Soviet works on language of that period) were characterised by the obligatory quotation or two from Stalin's work. Some linguists went further and wrote articles explicitly based on Stalin's writings on language. ${ }^{10}$

Nevertheless, to see the development of the Byelorussian literary language over this period purely in terms of Russianisation would be to take too simple a view. In 1951 an Orthographical Commission of the Institute of Language, Literature and Art of the Byelorussian Academy of Sciences published its Prajekt źmien i ŭdakładnieńniaŭ biełaruskaha pravapisu. As its title suggests, this was mainly concerned with problems of orthography, but like its 1930 counterpart it also examined certain grammatical points. In very few respects could its proposals regarding the latter be said to represent an attempt at Russianisation. It is true that it recommended the unification of the genitive plural of third declension nouns by the absolute use of the ending -ей(-э̆̆) - the characteristic ending for such nouns in Russian - but at the same time it favoured the extension of the ending $-y$ in the genitive singular of masculine nouns of the second declension to some new lexical groups (for example the names of chemical elements), a strict delineation between the first person plural of the present/future tense of first conjugation verbs (-om, -ëm, -am, -em) and the first person plural imperative (-эм, -ем) and the use of the ending -аце́(-яце́) i.e. with the stress on the final syllable of the ending, for the second person plural of the present/future tense. By contrast in Russian the use of the genitive singular ending $-y$ is restricted to a very small group of nouns and then only to particular constructions, the forms of the first person plural of the present/future tense and imperative mood coincide for all verbs, and the ending of the second person plural present/future tense is never stressed on the final syllable.

The publication of this plan provoked wide-ranging discussion: on

9. Wexler, op. cit., pp. 313-4.

10. For example, K. Krapiva, 'Pytańni biełaruskaha pravapisu ŭ śviatle vučeńnia I. V. Stalina ab movie', Vieści AN BSSR, 2, 1952. 
25-26 January 1952 a conference was held to discuss its proposals; a number of articles were written on these and other problems of the norms of literary Byelorussian, notably several by $\mathrm{M}$. H. Bułachaŭ, ${ }^{11}$ but it was not until 1957 that the Soviet of Ministers of the BSSR published its recommendations, which in almost all respects confirmed the proposals put forward in the 1951 prajekt. ${ }^{12}$ These recommendations were incorporated in the 1959 Pravity bielaruskaj arfahrafii $i$ punktuacyi, published by the Byelorussian Academy of Sciences, which remain the most recent official statement of the orthographical and punctuation norms of Byelorussian.

The year 1962 saw the publication of two works of great importance for the establishment of the norms of the Byelorussian literary language: a Byelorussian-Russian dictionary ${ }^{13}$ and the first volume of the Academy of Sciences Hramatyka bietaruskaj movy, which was devoted to morphology. ${ }^{14}$ In the succeeding years both these works, but principally the latter, have served as the foundation for the many grammars, collections of articles and in particular school textbooks which have appeared.

The Academy Grammar set itself two aims: to be descriptive but at the same time normative. ${ }^{15}$ Accordingly, in addition to setting out in great detail the morphological characteristics of Byelorussian it devotes considerable space to what it terms 'deviations from the norm' (adchilenni ad normy), the majority of which are to be found in the language of works of literature. In this connection it takes a particularly severe attitude towards deviations characteristic of the 1920 s and 1930 s but which are still to some extent perpetuated in modern times. While in the main the Academy Grammar's recommendations are consistent with the practice of the literary language, the twin aims of description and normalisation, perhaps inevitably, do not always co-exist entirely happily and some of the norms seem unnecessarily restrictive.

More than a decade has passed since the publication of the Academy Grammar - a decade in which scholars have become increasingly concerned with the 'culture of language' and in which a considerable amount of reappraisal has taken place of the norms of Byelorussian in the light of developments in the language over that period. In

11. 'Ab movie paeziji i litaraturnaj normie', Litaratura $i$ mastactva, 24 Oci. 1953; 'A b narmalizacyi biełaruskaj litaraturnay movy', Polymia, 11, 1953, pp. 136-46; 'Ab niekatorych py'tańniach narmalizacyi i raźvićcia biełaruskaj litaraturnaj movy', Pracy instytuta movaznaŭstva $A N B S S R$, I, 1954, pp. 5-24.

12. Pastanova Ab uảkładnieńni i častkovych źmienach isnujučaha biełaruskaha pravapisu, zaćvierdžanaja Savie'tam Ministraŭ BSSR 11 maja 1957 h.

Interestingly enough, the one proposal concerning grammatical normalisation contained in the 1951 prajekt which was not subsequently incorporated in the 1957 reform was the recommendation that the genitive plural ending of third declension nouns should be standardised as -ей(-эй), i.e. the proposal which more than any other could have been construed as an attempt at Russianisation of the Byelorussian literary language.

13. Biełaruska-ruski słoŭnik (ed. K. K. Krapiva), Moscow, 1962.

14. Hramatyka biełaruskaj movy, I, Marfalohija, Minsk, 1962. (Afterwards referred to in the text as the Academy Grammar.)

15. Ibid., p. 3 . 
recent years concern has begun to be expressed over the contamination of Byelorussian by Russian with the large numbers of people, particularly among the urban population, growing up apparently bilingual, but in reality only imperfectly so, with the result that they are not always able properly to distinguish between the two languages. ${ }^{16}$

The purpose of this article is to examine recent developments in the morphology of the Byelorussian noun and to attempt to establish their relationship to the literary norms laid down in the Academy Grammar which is still regarded as the definitive authority on the norms of the modern Byelorussian literary language.

\section{II}

Genitive singular of masculine nouns (second declension) ${ }^{17}$

The use of two different endings in the genitive singular of masculine nouns of the second declension, $-\mathrm{a}(\mathrm{g})$ and $-\mathrm{y}(-\mathrm{-}),{ }^{18}$ has always posed problems for grammarians attempting to establish norms for the literary language. These problems have been compounded, at least in part, by a certain confusion and inconsistency in the application of normative criteria. Thus, Taraškievič mixed semantic criteria with the criterion of stress position, ${ }^{19}$ while in the 1933 spelling reform, although mainly semantic criteria were used, the fact that the ending $-\mathrm{a}(\mathrm{g})$ was recommended for nouns denoting chemical elements and compounds was inconsistent with the longestablished tradition of using the ending - $y(-\circ)$ for a group of semantically related nouns - those denoting materials and substances. ${ }^{20}$ It was only in 1957 that this anomaly was eradicated by the recommendation of the ending -y(-ro) for nouns denoting chemical elements and compounds.

In the $1940 \mathrm{~s}$ and $1950 \mathrm{~s}$ - a period when Byelorussian was subject to considerable influence by Russian - the ending $-\mathrm{a}(-\Omega)$ tended to spread at the expense of the ending -y(-ю) even in those categories where the later had long been established as the norm. ${ }^{21}$ On the other hand in the dialects of Byelorussian the reverse trend is almost

16. In the recent Sučasnaja biełaruskaja mova, Minsk, 1973 the authors of several articles poin't to this as one of the major reasons for deviations from the literary norm: A. I. Padłužny, 'Normy biełaruskaha litaraturnaha vymaŭleńnia', pp. 6-7; M. V. Biryla, 'Nacisk', pp. 35-6, 46, 50; A. A. Kaŭrus, 'Užyvańnie asobnych słoŭ i vyrazaŭ', pp. 154-80 passim.

17. In accordance with the most widespread convention (not only in Byelorussian but in the Slavonic languages generally) the term 'second declension' is used in this article to refer to nouns of wha't is historically the o-s'iem declension, and 'first declension' for nouns of the pака́, зямля́ type (historically the a-stem declension). Somewhat confusingly, certain sources (including the Academy Grammar) use the reverse convention.

18. The ending $-y(-\circ)$ is not original in this declension but derives from the now defunci $u$-stem (fifth) declension.

19. Taraškievič, op. cit., p. 73.

20. Historyja bietaruskaj litaraturnaj movy, II [by I. I. Kramko, A. K. Jurevič, A. I. Janovič], Minsk, 1968, p. 297.

21. M. A. Žydovič, Nazoŭnik u biełaruskaj movie, I, Adzinočny lik, Minsk, 1969, pp. 70-5. 
universal: the ending $-\mathrm{y}(-\mathrm{-})$ is widely used in those semantic categories in which $-a(-я)$ is regarded as the norm in the literary language..$^{2 \cdot 2}$

The Academy Grammar, following on from the 1959 Pravity bietaruskaj arfahrafii i punktuacyi which in turn reflected the recommendations of the 1957 spelling reform, gives the following rules for the use of the endings $-a(-9)$ and $-y(-10)$ in the genitive singular of masculine nouns of the second declension: ${ }^{23}$

A. The ending $-a(-\Omega)$ is to be used for nouns denoting:

(a) animate beings, e.g. чалаве́к - чалаве́ка, конь - каня́, Міхаі́л - Міхаі́ла, лёў — льва;

(b) concrete objects which are numerable, e.g. стол - стала́, нож — нажá, мяшо́к - мяшка́, руча́й — ручая́;

(c) social organisations, enterprises, establishments, e.g. прафрсаю́з - прафсаю́за, калга́с - калга́са;

(d) geographical and astronomical terms, nouns denoting inhabited areas, e.g. Мінск - Мі́нска, Дняпро́ - Дняпра́, Ме́сяц - Ме́сяца, Mapc - Mápca;

(e) units of measurement of time, weight, currency, e.g. год го́да, кастры'чнік - кастры'чніка, чацве́р - чацвярга́, 'кіламе́тр — кіламе́тра, рубе́ль - руболя́;

(f) parts of the body, e.g. нос - нóca, хвост - хваста́. NB: an exception is made for твар which has genitive singular тва́pу;

(g) some concrete concepts (mainly mathematical and linguistic terms), e.g. квадра́т - квадра́та, назо́ўнік — назўніка.

B. The ending $-y(-\mathrm{IO})$ is to be used for nouns in the following semantic categories:

1. Abstract nouns denoting:

(a) intellectual concepts, qualities and characteristics, e.g. прагрэ'c - прагрэ'су, во́пыт — во́пыту, звы'чай — звы'чаю, гераі́зм - гераíзму;

(b) processes, actions, states, emotions, feelings, e.g. paзбóp разбо́ру, напа́д - напа́ду, бег — бе́гу, спако́й - спако́ю, боль бо́лю, гнев - гне́ву;

(c) spatial and temporal concepts, e.g. усхо́д - усхо́ду, за́хад за́хаду (but NB: по́ўдзень - по́ўдня presumably by analogy with дзень - дня), свет - све́ту, аб'ём - аб'ёму, край — кра́ю, мо́мант - мо́манту, век - ве́ку;

(d) social groupings, socio-political and scientific movements, scientific theories etc., e.g. капіталі́зм - капіталі́зму, дарвіні́зм дарвінізму, рэалі́зм - рэалі́зму, футуры'зм - футуры'зму. NB: specific exception is made for камуні́зм - камуні́зма, сацыялі́зм - сацыялі́зма, марксі́зм - марксі́зма, леніні́зм - леніні́зма which 'by tradition' take the ending -a;

(e) natural phenomena, e.g. ве́цер - ве́тру, хо́лад - хо́ладу, сухаве́й - сухаве́ю, пажа́р - пажа́ру.

22. Narysy pa biełaruskaj dyjalektatohii, Minsk, 1964, p. 155.

23. Hramatyka biełaruskaj movy, I, pp. 48-51. 
2. Nouns denoting substances, materials, e.g. тыту́нь - тытуню́, чай - ча́ю, дым - ды'му, цэме́нт - цэме́нту, ву́галь - ву́галю, клей — кле́ю, кісларо́д - кісларо́ду, азо́т — азо́ту. NB exceptions хлеб — хле́ба and авёс — аўса́.

Names of trees take either ending depending on whether one is referring to the tree itself or the wood obtained from it. Cf.: 3 клёна па́дала лі́сце ліне́йка зро́блена 3 клёну a ruler made from maple (wood)

3. Collectives, e.g. лес - ле́су, нато́ўп — нато́ўпу, тава́p — тавápy, пралетарыя́т - пралетарыя́ту, флот — фло́ту, хво́йнік - хво́йніку. NB: наро́д takes either ending with a semantic difference: сабра́лася мно́га наро́ду many people gathered гісто́рыя белару́скага наро́да the history of the Byelorussian people 4. Additionally the ending $-\mathrm{y}(-\circ)$ is used in a number of set expressions, a few of which involve nouns normally taking the ending -а(-я) е.g. з го́ду ў год, без го́ду ты'дзень (сf. го́да).

Despite this detailed exposition of normative rules recent research has shown that there are still many deviations from the literary norm. Thus H. U. Arašonkava, in an analysis of the language of newspapers and periodicals published between 1969 and 1972, finds that the only categories in which the norms are consistently adhered to are the semantic groups of animate beings and parts of the body. ${ }^{24}$ Although in many instances it is hard to understand why these violations occur - e.g. the use of the ending $-\mathrm{y}(-\circ)$ for such concrete nouns as твор, тэлефо́н, павільён or of the ending -a(-я) for some nouns denoting substances (пяска́, га́за) - in other instances their occurrence may be seen as resulting from analogy with words of similar meaning or composition, or from the occasional apparently arbitrary exception in the assignment of endings to nouns in a given semantic category, as well as the very real difficulty in some cases of determining whether a given noun is abstract or concrete.

Analogy can be seen in, for example, the use of the ending -y for a noun such as во́даправо́д - compare the cognate про́вад and the semantically similar ка́бель, for both of which the ending -y is the norm; in the use of го́ду (for го́да) outside the set expressions з го́ду у год, год ад го́ду, без го́ду ты'дзень etc; and in the form ay̆сý (for ay̆cá), авёc being one of only two nouns denoting a substance which are exceptions to their particular semantic category in taking the genitive singular ending -a. In the example of ay̆cý quoted by Arašonkava analogy is reinforced by the contextual proximity of a semantically cognate noun: залаці́стыя хва́лі жы'та і пшані́цы, аўсý і ячме́ню (quoted from Črvonaja źmiena, 25 March 1969).

Where a noun may take either ending in the genitive singular with different semantics, it is clearly easy for contamination to take place. Such contamination could ultimately lead to the generalisa-

24. H. U. Arašonkava, 'Da pytańnia ab niekatorych skłonavych formach nazoŭnikaŭ', Sučasnaja bietaruskaja mova, Minsk, 1973, p. 63. 
tion of one ending, although there is as yet no evidence of this having happened in the literary language. Nevertheless a considerable amount of fluctuation occurs in such nouns, for the most part involving the use of the ending $-\mathrm{y}(-\mathrm{-})$ where the meaning and context demand $-\mathrm{a}(-\mathrm{g})$. Thus, it is generally accepted that the noun наро́д should take the ending -y in the genitive singular only after quantitative words such as мнóra, мáлa etc. i.e where it means people = crowd; in the meaning of people = nation the correct ending is -a. Arašonkava quotes a number of examples of this norm being violated, mainly by the use of $-y$ for $-a$, and finds only one instance of $-\mathrm{a}$ incorrectly replacing $-\mathrm{y} .{ }^{25}$ Other nouns in which this kind of contamination takes place with the ending -y being used in place of -a include: суд = court, the ending $-y$ being correct only where the meaning is thought, idea, conclusion; зага́д and дагавóp when denoting documents rather than actions; пад'е́зд in the meaning of entrance as opposed to approach in the abstract sense.

Particular problems are posed by nouns in which the 'concreteness' or 'abstractness' of their meaning is not sufficiently welldefined for them to be readily assigned to a given semantic category, or by nouns which, though basically abstract in meaning, are frequently used in a concrete or particularised way. Here again there is hesitation between the two possible endings and among the nouns in which it occurs are пада́так, бюджэ'т, жанр, працэ'нт, ука́з, абаро́т, сюжз'т, варыя́нт. A. I. Narkievič feels that this situation probably arises because it is scarcely possible in formulating rules to legislate for each individual lexical item. ${ }^{26}$ However, both the Biełaruska-ruski słoŭnik and the authors of a more recent orthographical dictionary seem to have no such inhibitions, giving -a as the correct ending for the nouns працэ'нт, ука́з, сюжэ'т, варыя́нт and -y for the nouns пада́так, бюджэ'т, абаро́т and жанр. ${ }^{27}$

Fluctuation between the two possible endings of the genitive singular of masculine nouns of the second declension is also widespread in a group of nouns associated with sport: чэмпіяна́т, турнір, тэ'ніс, валейбо́л, бокс, футобо́л, хаке́й etc. Arašonkava has no hesitation in declaring the ending $-a(-\Omega)$ to be the norm for such nouns. ${ }^{28}$ Although this would seem appropriate in the case of чэмпіяна́т and турні́p since these two nouns would come under the Academy Grammar's category of 'concrete concepts', it makes much less sense in the case of nouns denoting names of sports. The latter would not seem to be covered by any of the semantic categories defined by the Academy Grammar as requiring the ending -a(- 9$)$; nor do they meet the criterion suggested by $\mathrm{K}$. Krapiva, namely

25. Ibid., p. 62, е.g. любо́ў да белару́скага наро́ду (Połymia, 5, 1969, p. 6); барацьба́ наро́ду Ірла́ндыi (Viačerni Minsk, 9 Oct. 1969); мно́га наро́да (Litaratura i mastactva, 5 Nov. 1971).

26. A. I. Narkievič, Varyjantnaść skłonavych form nazoŭnikaŭ in Ab niekatorych asablivaściach biełaruskaj litaraturnaj movy, Minsk, 1965, p. 72.

27. M. P. Łoban, M. R. Sudnik, Arfahrafičny słoŭnik dla siaredniaj školy, 3rd ed., Minsk, 1971, pp. 209, 247, 236, 90 and 189, 88, 59, 114.

28. Arašonkava, op. cit., p. 60. 
that 'the endings $-\mathrm{a}(-\mathrm{g})$ are taken in the genitive case... by nouns which can be used with the element па.у and the things denoted by them considered as units. ${ }^{29}$ Indeed this criterion and the fact that they clenote basically absiract concepts (albeit with a concrete manifestation) would if anything tend to classify them with those nouns which require the ending $-y(-\circ)$. The fact remains that Arašonkava is undoubtedly expressing the normative view: in Eoban and Sudnik's Arfahrafičny sioŭnitk the genitive singular ending for all sports is given as $-a(-x)$. Perhaps the confusion which exists is best summed up in one of the examples quoted by Arašonkava as a violation of the literary norm: зага́дчьк ка́фредры футтбо́ла-хаке́ю (my italics) Белару́скага інстыту́та фізкульту́ры (Viačerni Minsk, 1 October 1969).

If none of the violations of the norms laid down by the Academy Grammar described so far can be said to have acquired the status of a literary norm or to have become an acceptable literary variant, this does seem to have happened with one small group of words. These are the nouns гамуні́зм, леніні́зм, марксі́зм, сацыялі́зм, formerly constituting specific exceptions to the general rule for nouns in their particular semantic category (see above) in that they took the ending -a in the genitive singular whereas such nouns as гапіталísм, дарвіні́зм, фармалі́зм etc. took -y. Why these four nouns should have constituted an exception to the rule remains unclear. Certainly it would be difficult to justify this situation on linguistic grounds: the nouns involved are indisputably abstract in meaning, which places them firmly among those which require -y in the genitive case, and as far as formal considerations are concerned they belong to the most homogeneous of all the semantic categories isolated by the Academy Grammar, all nouns in this category having a common suffix -ізм(-ызм). Indeed, the Academy Grammar makes no attempt to justify the use of the ending -a on such grounds, simply stating that the nouns concerned have this ending 'by tradition'. However, this seems a doubtful criterion on which to base a normative rule, particularly in view of the fact that at the same time the Academy Grammar uncompromisingly rejects a number of the literary traditions of the first half of the twentieth century with regard to the genitive singular ending of nouns in other semantic categories. ${ }^{30}$ When one considers the associations of the four nouns concerned one is tempted to see here the influence of an extra-linguistic factor and one is reminded of the exceptions to the spelling rules for unstressed vowels formerly made for international words denoting concepts of the revolutionary era'. ${ }^{31}$

29. Quoted by Arašonkava, ibid., p. 64.

30. For example, the use of the ending -y for nouns denoting towns and other inhabited areas (Мíнску, пасёлку) or for the nouns сказ and твор.

31. N. I. Hurski, M. H. Bułachaŭ, M. C. Marčanka, Biełaruskaja mova, 2nd ed., Minsk, 1958, I, pp. 91-2. Examples included сове́т, комунізм, большэві́к, пролетарыя́т. In the 1957 spelling reform, however, these vords were brought in'to line with the general pattern of the languafe and are now written with a for unstressed o, э - саве́т, камуні́зм, бальшаві́к etc. 
Whatever the reasons, the fact remains that as far as the Academy Grammar is concerned the genitive singular ending $-\mathrm{a}$ is the norm for the nouns камуні́зм, леніні́зм, марксі́зм and сацыялі́зм. Grammars and textbooks published in the 1960s support this view and even the third and most recent edition of Łoban and Sudnik's Arfahrafičny słoünik gives only the ending -a as correct. ${ }^{32}$ Some scholars, however, clearly feel this distinction to be no longer valid or at best artificial. Thus M. C. Kavalova and P. U. Sciacko, in a textbook on modern Byelorussian published in 1970, in seiting out the categories requiring the ending $-y$ in the genitive singular list камунізм, ленінізм, марксі́зм, сацыялі́зм along with матэрыялізм, дарвіні́зм, рэалі́зм еtс. ${ }^{33}$

This view is shared by A. Kaŭrus, who favours the spread of the ending $-\mathrm{y}(-\mathrm{IO})$ to several categories where $-\mathrm{a}(-\Omega)$ is at present the norm. He makes the point in an article in Zviazda ${ }^{34}$ in reply to $€$. Burak who, in an earlier article in the same newspaper, argued for the reverse development. ${ }^{35}$ Burak favoured the abolition of the ending $-y$ to avoid ambiguity between the genitive and dative singular cases in such expressions as ацэ'нка фотурызму, пагро́за імперыллі́зму etc. Such a change would, however, need to be artificially imposed in the face of a persistent trend towards the predominance of the ending $-\mathrm{y}$.

\section{Prepositional singular of masculine nouns (second declension)}

Both masculine and neuter nouns of the second declension have a variety of endings in the prepositional singular: $-e$, the original ending for nouns of this (o-stem) declension with a stem ending in a hard consonont (although, of course, the consonant softens before the ending); - $i$, the original ending for o-stem nouns with a stem ending in a soft consonant, and -ы, its equivalent after formerly soft consonants (ж, ш, ч, p, ц); -y(-IO), originally the prepositional singular ending of the now defunct $u$-stem declension. The distribution of these endings in modern Byelorussian, however, no longer coincides in all instances with their distribution historically. This has resulted in a certain amount of duality of endings and created a climate in which there is considerable deviation from the literary norm.

Neuter nouns of the second declension show very little fluctuation in the endings used in the prepositional singular. This is in large measure due to the fact that the endings are determined solely on the basis of formal considerations: -e after a hard consonant; -ы after the formerly soft consonants ж, ч, ш, p, ц; -i after soft consonants (including [j]); and $-\mathrm{y}$ after stems in $\mathrm{K}$, $\mathrm{x}$ (which eradicates the consonant alternation $\mathrm{K} / \mathrm{L}, \mathrm{x} / \mathrm{c}$ ). Isolated exceptions

32. It is interesting to note that in an introductory section on the orthography of certain endings (p. 36) the authors make no mention of these four nouns constituting exceptions to the norm in their semantic category.

33. M. C. Kavalova, P. U. Ściacko, Bietaruskaja mova, Minsk, 1970, p. 84.

34. A. Kaŭrus, 'Narmalizavać, ale nie źbiadniać', Źviazda, 1 Sept. 1965.

35. Ł. Burak, 'Jak my pišam', Zviazda, 4 June 1965. 
are малако́ which has a prepositional singular in -э( <-e) - малацэ', and the dual endings -ы and -э for the noun вядро́ - вядры'/ вядрэ'.36

With masculine nouns the picture is very different. Here endings are prescribed on the basis of a mixture of formal and semantic criteria, and the Academy Grammar lays down the following literary norms: ${ }^{37}$

1. The ending -e is used for the majority of nouns with a stem ending in a hard consonant or $\ddot{y}$ and also for some nouns with a stem ending in the velar consonants $r$ or $x$. In the latter case the velars show palatalisation to the sibilants, 3, c. Examples: (аб) ду́бе, маро́зе, го́ласе, ку́це, во́страве, бе́разе, кажу́се. Colloquially, stressed $-\dot{y}$ is also used for some of these nouns e.g. (у) тылý, кажуху́; occasionally there is a semantic distinction between the two endings: на вугле́ зру́ба — на вуглу́ ву́ліцы.

2. The ending -ы is used for nouns with a stem ending in p, ц, ж, ш, ч, e.g. (аб) бары', рубяжы', пля́цы. An earlier distinction between двары' (as in на двары' заво́да) and дварэ' (as in на дварэ' хо́ладна) is regarded as no longer valid.

3. The ending $-i$ is used for nouns with a stem ending in a soft consonant or [j], e.g. (аб) ты'дні, вестыбю́лі, пако́i.

4. The ending $-\mathrm{y}(-\circ)$ is used by nouns in the following categories:

(a) all common nouns denoting human beings, regardless of stem, e.g. (аб) бра́ту, сы'ну, металу́ргу, гаспада́ру, му́жу, кавалю́.

(b) proper names with stems in p, ц, ж, ш, ч, soft consonants, [j], г, к, x, е.g. (аб) Алякса́ндру, Ме́лежу, Лука́шу, Маку́цю, Багдано́вічу, Васі́лю, Андрэ'ю, Краўчуку́, Цімо́ху.

NB) Proper names with a stem in a hard consonant take -e, e.g. (аб) Гле́бе, Максі́ме, Ко́ласе.

(c) some concrete nouns with a stem ending in $\Gamma, \mathrm{x}$, e.g. (аб) сци́гу, пірагý, мяхý, мо́ху, цэ'ху, шля́xy.

(d) abstract nous with the stem ending in $г$, x, e.g. (аб) бе́гу, по́дзвігу, сме́ху, стра́ху, рýxy, размáху.

(e) all nouns with a stem ending in к, е.g. (аб) до́світку, пача́тку, здабы'тку, баравіку́.

(f) loan-words with a stem in $\Gamma$, к, x, e.g. (аб) абшла́гу, дыфто́нгу, бло́ку, дру́ку, мі́тынгу, ша́ху.

(g) certain nouns, normally taking the ending -e, when used in set expressions with the prepositions y, на, па, e.g. у ладу́ (cf. аб ла́дзе), у кругу́ (cf. аб кру́зе), на раду́ (cf. аб ра́дзе), па хо́ду (cf. аб хо́дзе).

Most violations of these norms involve the ending $-y(-ю)$ either spreading to categories where it is not prescribed or conversely not being used in those categories where it is prescribed, and in this

36. Hramatyka biekaruskaj movy, t. I, p. 64.

37. Ibid., pp. 52-6. 
respect the most contentious area is the semantic category of common nouns denoting human beings.

The majority of textbooks and other works on the grammar of modern Byelorussian which have appeared since 1962 support the Academy Grammar's view that the ending -y(-ю) is the norm for all common nouns of the second declension denoting human beings regardless of stem and that the use of the endings -e (after hard consonants), -ы (after p, ц, ж, ш, ч), -i (after soft consonants and [j]) is a violation of the literary norm, although frequently encountered in works of literature. ${ }^{38}$

Not all scholars agree with this assertion. Thus, Arašonkava considers that the Academy Grammar's dictum goes against the recommendation of the 1957 spelling reform that for nouns with a stem ending in a hard consonant the ending is -e, no exception being made for common nouns denoting human beings. ${ }^{39}$ Furthermore, she expressly states that the use of the ending -y in the prepositional singular for such nouns should be regarded as a violation of the literary norm, and sees its occurrence in the literary language as being due to dialect influence. ${ }^{40}$ That the ending $-y$ is widespread in Byelorussian dialects in nouns of this category is supported by the findings of M. A. Žydovič; indeed, in dialect speech it also embraces the category of proper names, a category specifically excepted by the Academy Grammar. In the literary language, however, Žydovič notes two seemingly contradictory trends: on the one hand, the spread of the ending -y(-ю) to all categories of masculine nouns in the prepositional singular, but on the other hand a tendency to preserve the old endings. Significantly, it is precisely in nouns denoting human beings that the latter tendency is most evident. ${ }^{41}$

Arašonkava only admits the ending $-\mathrm{y}(-\circ)$ for common nouns denoting human beings if they have a stem ending in a formerly soft consonant ( $p, ц, ж, ч, ш)$, a soft consonant or a velar $(\kappa, r, x)$ i.e. she sees them as subject to the same normative rules as proper nouns. Somewhat surprisingly this view is shared by Łoban and Sudnik who, in the introduction to their Arfahrafičny słoŭnik (third edition), give the following examples: партыза́н - аб партыза́не, брат - аб бра́це, Яккуб - аб Якубе, Чэ'хаў - аб Чэ'хаве; кава́ль - аб кавалю́, Міха́сь - аб Міха́сю, Васі́ль - аб Васі́лю, Го́галь - аб Го́галю, Мікала́й - аб Мікала́ю; наста́ўнік - аб наста́ўніку, дзе́яч аб дзе́ячу, качага́р - аб качага́ру, Але́г - аб Але́гу, Ме́леж - аб Ме́лежу, Гайда́p - аб Гайда́ру, Ко́бец - аб Ко́бецу. ${ }^{42}$ This is the more surprising in view of the normative character of the Arfahra-

38. M. S. Jaŭnievič, U. K. Andrejenka, Bietaruskaja mova, I, Fanietyka i pravapis, marfałohija, 3rd ed., Minsk, 1965, p. 69; U. V. Aničenka, Marfatohija uschodniestavianskich moū. Nazoŭnik. Dziejasłoŭ. Prystoŭje, Minsk, 1973, p. 18; Narkievič, op. cit., p. 76; Historyja biełaruskaj litaraturnaj movy, II, pp. 299-300; J. M. Kamaroŭski, Bielaruskaja mova. Arfahrafija, Minsk, 1972, p. 78.

39. Arašonkava, op. cit., p. 64.

40. Ibid., p. 66 .

41. Žydovič, op. cit., pp. 113-4.

42. Łoban, Sudnik, op. cit., pp. 36-7. 
fičny słoŭnik, its avowed concern with the 'culture of language' and its reiteration in general of the norms prescribed by the Academy Grammar.

Narkievič takes the opposite view to Arašonkava and Łoban and Sudnik. In supporting the contention that the use of the ending -e in the prepositional singular of common nouns with a stem ending in a hard consonant which denote human beings is now a violation of the literary norm, he suggests that it would be better to extend the use of the ending -y to proper nouns denoting human beings, thereby eradicating an anomaly which is in any case highly susceptible to the effects of analogy - one already comes across such forms as Іва́ну, Сцяпа́ну in works of literature. ${ }^{43}$ So far, however, he seems to have no support among other scholars of Byelorussian for this proposal and for the present the norm for such nouns remains as defined in the Academy Grammar.

The mixture of formal and semantic criteria used in determining the prepositional singular ending for masculine nouns of the second declension has led to other violations of the norms. In the main these have consisted in the disregarding of semantic criteria in favour of analogy on the basis of formal considerations.

The ending - $\dot{y}$ is found in some inanimate nouns with a stem ending in a hard consonant e.g. на масту́, у тылу́, на гарбу́ (for на мо́сце, у ты'ле, на гарбе́). These forms are undoubtedly influenced by the existence in Byelorussian of a number of set expressions in which the ending -ý is normal (cf. на ляту́, у хаду́ etc.), but the spread of this ending may also indicate the influence of Russian where such forms occur in a large number of (mainly monosyllabic) nouns when used in conjunction with the prepositions $\mathbf{в}$ and на and having strictly locative meaning. ${ }^{44}$ In Byelorussian, by contrast, the number of such nouns is small, and the only inanimate noun with a stem ending in a hard consonant (excluding the velars, chuitantes, $p$ and 4 ) regularly taking the ending $-\mathrm{y}$ as the literary norm is пост ${ }^{45}$

Nouns with a stem ending in the velar consonant $\mathrm{K}$ show no deviations from the norm but in those with a stem ending in either of the other velar consonants $(r, \mathrm{x})$ there is a considerable amount of fluctuation in the endings: $-y$ replacing -e and, conversely, -e replacing $-y$. In the latter instance this is partly due to the preservation of the alternation between the velars $\mathrm{r}, \mathrm{x}$ and the sibilants $3, \mathrm{c}-$ an alternation which was previously characteristic of all nouns with a stem ending in a velar consonant and which dates from the Common Slavonic period; however, in both situations it is morphological analogy which is largely responsible. As far as the literary norm is concerned, in broad terms there is a division between nouns with a stem ending in $r, \mathrm{x}$ denoting concrete objects (which take the ending -e with the appropriate palatalisation of the final stem consonant e.g бépar -

43. Narkievič, op cit., pp. 80-1.

44. Grammatika sovremennogo russkogo literaturnogo jazyka, Moscow, 1970, pp. $379-80$.

45. Hramatyka bielaruskaj movy, I, p. 53. 
бépaze, верx - вépce) and those denoting abstract concepts together with all loan-words (which take the ending -y e.g. бег - бе́гу, рух ру́ху, мі́тынг - мі́тынгу, шах — ша́ху). Formally, however, there is little to distinguish for example паро́г and падло́г, кажу́х and рух, and the existence of a small group of concrete nouns which regularly take -y (e.g. ло́г, абýx) only serves to increase the likelihood of morphological analogy. In these circumstances it is hardly surprising that such deviations from the norm as берагý, снягу́ (for lit. бépaзe, сне́зе) or cмéce, стрáce, pýce (for lit. cмéxy, стрáxy, pýxy are frequently encountered, both in dialect and the literary language; indeed, the Academy Grammar recognises the reality of this situation in the case of -ý replacing -e, considering it admissible in colloquial style or in the language of works of literature. ${ }^{46}$

Less readily understandable is a recent tendency in the press and in the spoken language for nouns denoting towns with the foreign suffix -бург/-берг to take the ending -e with consequent palatalisation of $г$ to 3 e.g. у Пецярбу́рзе, Арэнбу́рзе. This directly contravenes the norm for all loan-words with a stem ending in $r, \mathrm{x}$ : whether they be abstract or concrete nouns they take the ending -y e.g. катало́ катало́гу, крах — крáxy etc. ${ }^{47}$

Violations of the literary norm where the endings -ы and -i are concerned are also encountered in modern Byelorussian, both in the press and in works of literature, and once again illustrate the increasing trend towards the use of the ending $-\mathrm{y}(-\mathrm{-})$ at the expense of all other endings in the prepositional singular of masculine nouns of the second declension (e.g. про́дазку, пла́чy for lit. про́дажы, пла́чы and кра́ю, це́ню for lit. кра́i, це́ні). They are, however, noticeably less frequent than the violations outlined above, since morphological analogy does not have such a strong role to play in this instance; it is even conceivable that they represent a continuation of an earlier norm rather than an innovation. ${ }^{48}$

In the case of the noun двор the Academy Grammar considers the semantic distinction between the endings -ы (е.g. на двары' заво́да) and -э (е.g. на дварэ' хо́ладна) to be no longer valid and maintains that на двары' now serves for both meanings (i.e. in the yard outside), but in recent works on Byelorussian there is little support for this view. ${ }^{49}$ Arašonkava categorically rejects the replacement of на дварэ' by на двары' as contrary to the literary norm, classing

45. Ibid.

47. V. P. Lemciuhova, 'Ułasnyja hieahrafičnyja nazvy (skłanieńnie)', Sučasnaja biełaruskaja mova, Minsk, 1973, p. 91.

48. Bielaruski pravapis (prajekt), 1930, p. 25 allowed variants -b/-y and -i/-ro for masculine nouns with a stem ending in a formerly soft consonant and a sofi consonant respectively, but this cannot be considered a norm of modern Byelorussian.

49. See, among others, Kavalova, Sciacko, op. cit., p. 81; Arašonkava, op cit., p. 68. Qualified support for the Academy Grammar's point of view comes from Narkievič (op. cit., p. 82) who says tha' although the distinction between на двары' заво́да and на дварэ' хо́ладна is still valid, there has been an increasing tendency in recent years towards the generalisation of the ending -sr. 
двор with por and круг as nouns which have dual prepositional singular endings reflecting semantic differences, while the entry in Łoban and Sudnik's Arfahrafičny słoŭnik (third edition, 1971, p. 107) also observes the semantic distinction.

\section{Dative, instrumental, prepositional singular of masculine nouns (first declension)}

Although the first declension consists mainly of feminine nouns, it includes also a number denoting animate beings which are masculine in gender (е.g. ста́раста, ба́цька, суддзя́ and in particular proper names such as Кузьмá, Míша, Ілья́ etc.) and these exhibit certain peculiarities of declension. In the nominative, accusative and genitive singular all such nouns take the same endings as feminine nouns of the first declension, but in the dative, instrumental and prepositional singular the gender of these nouns now has some influence on their declension. Historically speaking, this is a relatively recent development: Taraškievič, for example, notes only the occasional use of such forms as ста́растам, з саба́кам, with the characteristic second declension masculine instrumental singular ending (unstressed) replacing the first declension ending -ай(-аю). ${ }^{50}$

The Academy Grammar shows an awareness of the spread of these second declension endings to masculine nouns of the first declension but is unable to formulate precise rules for their use, simply stating that masculine nouns in $-a(-9)$ decline like masculine nouns of the second declension. Among the examples quoted are: dative - ста́расту, Míшу, старшыню́; instrumental - ста́растам, дзя́дзькам, Вало́дзем; prepositional - ба́цьку, Кіры'лу. At the same time in the dative and prepositional singular the characteristic first declension feminine endings may be found (ста́расце, старшьпі), while in the instrumental singular the normal first declension ending -ёй(-ёю) is more common for the nouns суддзя́, старшыня́; proper names in -a with a hard stem and stress on the ending take the characteristic (feminine) first declension endings in all three cases (e.g. Кузьме́, Кузьмо́й, Кузьме́). ${ }^{51}$

Recent years, however, have seen further developments in this group of nouns and although a few scholars still allow variants for specific nouns, ${ }^{52}$ the majority favour stress as the determining factor in the endings of the dative, instrumental and prepositional singular. ${ }^{53}$ Masculine nouns of the first declension which are stressed on the ending take the same endings as feminine nouns of this declension: -é, -óй(-óю), -é for nouns with a stem ending in a hard consonant; -í, -ёй(-ёю), -í for those with a stem ending in a soft consonant e.g.:

50. Taraškievič, op. cit., p. 81.

51. Hramatyka bietaruskaj movy, I, pp. 76-8.

52. Narkievič, for example, (op. cit., pp. 92-3) gives alternatives ста́pacту/ста́расце, мужчы'ну/мужчы'не, старшыню́/старшыні (dative/prepositional singular); суддзём/суддзёй, старшынём/старшынёй (instrumental singular).

53. See, for example, Jaŭnievič, Andrejenka, op. cit., p. 64; Kavalova, Sciacko, op. cit., p. 82; Kamaroǔski, op. cit., pp. 80-1. 


$\begin{array}{lllll}\text { Dative } & \text { Кузьме́ } & \text { старшыне́ } & \text { суддзі } & \text { старшыні́ } \\ \text { Instrumental } & \text { Кузьмо́й } & \text { старшыно́й } & \text { суддзёй } & \text { старшынёй } \\ \text { Prepositional } & \text { Кузьме́ } & \text { старшыне́ } & \text { суддзі́ } & \text { старшыні́ }\end{array}$

while those stressed on the stem take the endings characteristic of masculine nouns of the second declension: $-y,-a m,-y$ (hard stem); -ю, -ем, -ю (soft stem) e.g.:

$\begin{array}{lllll}\text { Dative } & \text { ста́расту } & \text { ба́цьку } & \text { прамо́ўцу } & \text { дзяду́лю } \\ \text { Instrumental } & \text { ста́растам } & \text { ба́цькам } & \text { прамо́ўцам } & \text { дзяду́лем } \\ \text { Prepositional } & \text { ста́расту } & \text { ба́цьку } & \text { прамо̆ўцу } & \text { дзяду́лю }\end{array}$

This view is supported by the relevant entries in Eoban and Sudnik's Arfahrafičny słoŭnik. ${ }^{54}$

Nouns of common gender follow the same pattern if they denote masculine beings, but decline like first declension feminine nouns if they denote females, regardless of stress position.

\section{Genitive plural}

\section{(a) Masculine nouns (second declension)}

For the vast majority of nouns in this category the endings are: -оў (hard stem, final stress), e.g. стало́ў, брато́ў, нажо́ў, купцо́ў, вятро́ў, бераго́ў, юнако́ў; -аў (hard stem, non-final stress), e.g. нарóдаў, пала́цаў, по́дзвігаў; -ёў (soft stem, final stress), e.g. агнёў, краёў, вераб'ёў, шынялёў; -яў (soft stem, non-final stress), e.g. ву́чняў, трамва́яў. Nouns with the suffix -анін(-янін), -ін(-ын) in the singular have a zero ending, е.g. грамадзя́нін - грамадзя́н, мінча́нін - мінча́н, балга́рын - балга́p, as do the nouns чалаве́к and дзень (чалаве́к, дзён) and a group of nouns denoting electrical and magnetic units of measurement, е.g. вольт, ампе́p, ом, мікро́н etc. These norms are long-established and show no sign of undergoing change in modern Byelorussian.

A small number of second declension masculine nouns have alternative endings in the genitive plural and here there is some degree of fluctuation in usage and disagreement among scholars as to precisely which nouns are included in this group. The Academy Grammar gives the following nouns with a stem ending in a hard consonant as having alternative -оў(-аў) or zero: партыза́наў партыза́н, салда́таў — салда́т, гадо́ў — год, разо́ў — раз, кло́патаў клапо́т, аршы'наў - аршы'н, кілагра́маў — кілагра́м, баці́нкаў баці́нак, чараві́каў — чараві́к. ${ }^{55}$ Not all scholars accept these variants as having equal status in the literary language. Some admit the zero ending only for the nouns чалаве́к and дзень (where it is obligatory); $;^{56}$ others place contextual and semantic restrictions on the use

54. An isolated exception is ваяво́да (p. 91) for which the dative and prepositional singular is given as ваяво́дзе.

55. Hramatyka biełaruskaj movy, I, p. 56.

56. Narkievič, op. cit., p. 83; Z. Laksucina, 'Da py'tańnia narmalizacyji form nazoŭnikaŭ rodnaha skłonu množnaha liku', Filologičeskij sbornik. Materialy naučnoj konferencii, Aprel' 1966 g., Belorusskij gosudarstvennyj universitet im. V. I. Lenina, p. 158. 
of one ending or the other. Thus, Arašonkava suggests that for the noun год the zero ending in the genitive plural is used when the noun is dependent on a cardinal numeral (е.g. 12 год працу́е ня́няй), in titles (e.g. у калга́cax 'С́́рак год Кастры'чніка' і 'Перамо́га') and in some set expressions e.g. 3 ма́лых год, мужчы'на сярэ'дніх год); the genitive plural form гадо́y̆ is to be used in conjunction with ordinal numerals (е.g. у канцы' трыцца́тых гадо́y̆). Word order may also influence the choice of form - гадо́y predominates in contexts where the numeral follows the noun (e.g. мужчы'на гадо́ў трыццаці́ пяці́), although this is not an invioiable rule. ${ }^{57}$

All sources are agreed that the ending -ей is standard for the two nouns госць (гасце́й) and ла́паць (лапце́й) and most support the Academy Grammar's distinction between канёy̆ (after cardinal numerals, viewed as individual units) and ко́ней (after collective numerals, seen as an indivisible group). Laksucina, however, disagrees and contends that this separation is not a rigid one, quoting examples of both endings used in both types of context and commenting that the ending -ей осcurs far more frequently, ${ }^{58}$ and although Łoban and Sudnik (Arfahrafičny słoünik, p. 150) still insist on the distinction as the literary norm, it is questionable whether in practice this is consistently observed.

\section{(b) Neuter nouns (second declension)}

The norms prescribed by the Academy Grammar still hold good and little violation occurs, although the fact that nouns with a stem ending in a single consonant may take either the original zero ending or the ending -ay̆ (which has developed by analogy with the genitive plural ending of masculine ncuns of the second declension) is regretted by, for example, Arašonkava who feels that in the literary language it is 'desirable' that such nouns should have a zero ending in the genitive plural. ${ }^{50}$

\section{(c) Feminine nouns (first declension)}

The use of the ending -аў(лў) in the genitive plural of first declension feminine nouns, either instead of or as a variant to the original zero ending, is the subject of much discussion and division of opinion among scholars of Byelorussian.

There is general agreement that the ending -ay̆(-яy̆) is the norm for nouns with a stem ending in the consonant groups зв (адо́зваў), тв (бі́тваў), кв (цэ'ркваў), шв (падэ'шваў), др (вы'драў), ул' (будо́ўляў), дн' (сту́дняў), зн' (ла́зняў), ун' (харчэ' ўняў), льн' (чыта́льняў), жн' (тамо́жняў), лл' (эскадры'лляў), сц' (го́сцяў); that the zero ending is the norm for all nouns with a stem ending in a consonant group of which the last consonant is $\mathrm{K}$, the fill-vowel o/a being inserted before the к (е.g. дачóк, бу́дак, стрэ'лак, устано́вак, хма́рак, бяро́зak etc.); and that either ending may be used (a) without the insertion

57. Arašonkava, op. cit., pp. 70-1.

58. Laksucina, op. cit., p. 159.

59. Arašonkava, op. cit., p. 73 . 
of a fill-vowel if the zero ending is used after the consonant groups рб (верб - ве́рбаў), мб (бомб - бо́мбаў), мп (лямп - ля́мпаў), рт (сці́рт - сці́ртаў), хт (шахт - ша́хтаў), фм (рыфм - ры'фмаў), йн (тайн - та́йнаў), шч (пушч - пу́шчаў), зг (розг - ро́згаў), нг (штанг - шта́нгаў) or мx (чарómx - чарóмxay̆), and (b) with the insertion of a fill-vowel if the zero ending is used when the stem ends in the consonant groups сн (со́сен - со́снаў), стр (сясцёр сёстраў), бл' (грэ'бель - грэ'бляў), пл' (кро́пель - кро́пляў) or шн' (су́шань — су́шняў). ${ }^{60}$

With certain other consonant groups, however, the norm proposed by the Academy Grammar is questioned in more recent works, at least by implication. Thus, the Academy Grammar admits only the ending -ay̆(-яy̆) in the genitive plural for nouns with a stem ending in чб (лічбаў), рг (качэ' ргаў) or йн' (бо́йняў) but Narkievič is of the opinion that the zero ending is also acceptable, ${ }^{61}$ while Łoban and Sudnik recommend only the zero ending for бо́йня — бо́ень; ${ }^{62}$ and whereas the Academy Grammar, supported in most instances by Narkievič, allows alternative zero ending or -ay̆ for nouns with a stem ending in льх (вольх — во́льхаў), рн (цыстэ'рн - цыстэ'рнаў), рм (форм - фо́рмаў) оr чт (мачт - ма́чтаў) Łoban and Sudnik propose во́льхаў, цыстэ'рнаў, фо́рмаў, ма́чтаў as the sole normative forms in the literary language. ${ }^{63}$ With the consonant groups 3 н, мл', $\mathrm{xH}^{\prime}, \mathrm{TH}^{\prime}, \mathrm{cH}^{\prime}$ and $\mathrm{pH}$ ' Łoban and Sudnik are again more restrictive than the Academy Grammar, allowing only the zero ending (with a fill-vowel inserted between the consonants): баразён, зяме́ль, ку́хань, со́цень, пе́сень and майстэ'рань are their recommended genitive plural forms ${ }^{64}$ while the Academy Grammar allows the variants баразён баро́знаў, зяме́ль - зе́мляў, ку́хань - ку́хняў, со́цень - со́тняў, пе́сень - пе́сняў and майстэ'рань - майстэ'рняў. In fact, Łoban and Sudnik accept extremely few variants in the ending of the genitive plural not only of first declension feminine nouns, but also of neuter nouns of the second declension. ${ }^{65}$

For first declension feminine nouns with a stem ending in a single consonant (including [j]) the Academy Grammar, while acknowledging the frequent occurrence in works of literature of the ending -аў(-яў) in the genitive plural, regards this as a violation of the literary norm and recognises no exceptions to the zero ending e.g. бяро́з, школ, моў, веж, нор, даро́г, стрэх, фа́брык, змей, свіне́й etc. ${ }^{66}$ However, there is evidence to suggest that such a categorical rejection of the ending -ay̆(-яy̆) does not reflect the reality of usage in modern literary Byelorussian. There has long been a tendency for

60. Hramatyka biełaruskaj movy, I, pp. 73-4; Narkievič, op. cit., p. 90; Łoban, Sudnik, op. cit., passim.

61. Narkievič, op. cit., p. 90.

62. Eoban, Sudnik, op. cit., p. 86.

63. Ibid., pp. $73,259,254,167$.

64. Ibid., pp. 83, 133, 153, 231, 202, 162.

65. Thus, for example, only ако́н, азёр, вёдзер are given as the genitive plural forms of акно́, возера, and вядро́ respectively (ibid., pp. 72, 93, 98).

66. Hramatyka bielaruskaj movy, I, p. 72. 
this (originally second declension masculine) ending to spread to other declensions, a fact which was observed in his time by Taraškievič. Although he noted that the zero ending was predominant he he also pointed out that the ending -ay̆(-яy̆) was widespread and gave only two nouns as having the zero ending at all times: рука́ (рук) and нага́ (ног). Furthermore, in his 'patterns of declension' for feminine nouns he gave only the -аў(-яў) ending in the genitive plural for the nouns калі́на (калі́наў) and зара́ (зо́раў). ${ }^{67}$

By comparison with the 1920s and 1930s the use of the ending -аў(-яў) in the genitive plural of feminine nouns of the first declension has increased considerably, although the zero ending still predominates. ${ }^{68} \mathrm{~A}$ major contributory factor in this development has been the widespead use of the ending -ay̆(-яy̆) in Byelorussian dialects, whence it has penetrated the literary language and become established, so much so that for some nouns it has become not just an alternative, but the norm, ousting the original zero ending in the process. Thus, Arašonkava while in general supporting the Academy Grammar - she feels it is 'more correct' to use the zero ending for nouns with a stem ending in a single consonant - accepts the ending -аў(-яў) as the norm for a few bisyllabic nouns, among them за́ла за́лаў, ро́ля - ро́ляў, пя́дзя - пя́дзяў, ғззяжа́ - дзе́жаў, ша́фа Iuácpay̆, ${ }^{69}$ and even Łoban and Sudnik, who show a marked resistance to the spread of this ending (of 169 nouns in this category for which they give the genitive plural form, the zero ending is recommended in 157 cases and alternative zero/-аў(-яy̆) in only 3 - абло́г/абло́гаў, во́далячэ'бніц/во́далячэ'бніцаў, імша́р/імша́pаў), recommend the ending -аў(-яў) in the following 9 instances: браняве́жаў, дзе́жаў, за́лаў, зме́яў, ідыёмаў, карыяты' даў, кіназа́лаў, ме́жаў, ро́ляў. ${ }^{70}$

As far as the use of the ending -аў(-яў) as an alternative to the zero ending is concerned, most recent grammars and text-books acknowledge its literary status in such examples as галóy̆/галóваў, нор/но́раў, зім/зімаў, школ/шко́лаў, хат/ха́таў etc., but emphasise that the zero ending is still dominant (and for some, preferable) in the majority of nouns with a stem ending in a single consonant. ${ }^{71}$ Clearly the spread of the ending -ay̆(-яy̆) is very much a live feature of contemporary Byelorussian and one which appears to be gaining ground all the time, although it is as yet premature to predict a single flexion for all nouns in the genitive plural. ${ }^{72}$

First declension masculine nouns and nouns of common gender follow the same pattern and are subject to the same influences in the ending of the genitive plural as feminine nouns of this declension.

67. Taraškievič, op. cit., pp. 79-81.

68. Laksucina, op. cit., p. 161.

69. Arašonkava, op. cit., p. 75.

70. Eoban, Sudnik, op. cit., pp. 87, 109, 121, 131, 134, 146, 148, 174, 220.

71. Jaŭnievič, Andrejenka, op. cit., p. 76; M. I. Hurski, Paraŭnalnaja hramatyjka ruskaj i bietaruskaj moŭ. Fanietyka i marfatohija, 2nd ed., Minsk, 1972 , p. 98; A. A. Krivickij, A. E. Michnevič, A. I. Podlužny, Belorusskij jazyk dlja nebelorusov, Minsk, 1973, pp. 84-5.

72. Laksucina, op. cit., p. 163. 


\section{(d) Feminine nouns (third declension)}

If the spread of the ending -аў(-яў) to feminine nouns of the first declension is the subject of discussion among linguists and scholars of modern Byelorussian, then its use in the genitive plural of feminine nouns of the third declension is a matter of controversy. That it is widely used is not denied; what is questioned is its status in the literary language, and in this connection it is worth tracing the history of the occurrence of this ending in third declension nouns over the past fifty years.

For Taraškievič the two endings -ей(-эй) and ай(-яй) appear to have had equal status as literary variants, though admittedly he only quoted examples with the ending -ay̆ in which the final stem consonant is a chuintante: касьце́й, сане́й, грудзе́й, пе́чаў, рэ'чаў, но́чаў (sometimes пячэ'й, начэ'й еtc.) ${ }^{73}$ However, other sources are agreed that in the early part of the twentieth century the ending -аў(-яў) was widespread (probably under the influence of dialect usage) both for nouns with a stem ending in a chuintante and also for those with a stem ending in a soft consonant or a labial. Indeed, the reality of this situation was recognised by the 1933 spelling reform which sanctioned the use of either -ей(-эй) or -ay̆(-лў) in the literary language. ${ }^{7 t}$ This in turn conditioned extensive parallelism of such forms in literature.

Later, however, there seems to have been a reaction on the part of those concerned with the standardisation of the literary language to the use of the ending -ay̆(-яy̆). Thus the Kurs sučasnaj biełaruskaj movy (1941) characterised it as a dialecticism which should be regarded as a violation of the literary norm, and this was echoed by the Prajekt źmien i ŭdakładnienniaŭ biełaruskaha pravapisu published in 1951. Bułachaŭ, in his article on the normalisation of the Byelorussian literary language published in 1954, argues that only the ending -ей is acceptable in the literary language on the grounds that all words which are grammatically homogeneous are subject to a single grammatical law, which he appears to regard as immutable, and claims that this is supported by 'the whole course of historical development of the language'. ${ }^{75}$ In effect what he is saying is that what is the norm at one stage in the history of a particular grammatical form or category must always remain so. Such a premise is demonstrably untrue, ignoring as it does the forces of morphological analogy which in any language are capable of modifying or indeed radically altering established norms, and represents the worst kind of purism - imposing restrictions on the language from outside which are not justified by actual usage, rather than examining normal usage and attempting a classification on the basis of it. From the general tenor of this article one is inclined to suspect nothing more nor less than a tacit attempt at Russianisation.

These calls for the unification of the genitive plural ending of

73. Taraškievič, op. cit., p. 83.

74. Historyja bietaruskaj litaraturnaj movy, II, p. 300; Narkievič, op. cit., p. 96.

75. Bułachaŭ, Ab niekatorych pytańniach ..., pp. 7-8. 
third declension nouns were not heeded by the 1957 spelling reform; it made no recommendation on this point, thereby implicitly accepting the literary status of both variants which had been established by the 1933 spelling reform. However, the controversy was not yet resolved. The Academy Grammar, which in general implemented the recommendations of the 1957 pastanova, made an exception in this case, proposing only a very limited use of the ending -ay̆: after a chuintante unstressed, e.g. рэ'чаў. Otherwise the ending -ей(-эй) was to be regarded as the norm (e.g. во́сей, сенажа́цей, да́лей, начэ'й, пячэ' й). ${ }^{76}$

Since the publication of the Academy Grammar in 1962 the debate has continued. Support for the view that only the ending -ей(-эй) is correct in the literary language is given by, among others, Narkievič, who, while acknowledging that the ending -ay̆(-яy̆) had literary status 'in the first half of the twentieth century', quite definitely regards its use in modern times as a violation of the literary norm (with the sole exception of рэч — рэ'чаў). ${ }^{77}$ Qualified support comes from Laksucina who regards -ей as normative but recognises that -ay̆(-яў) is spreading 'by analogy with feminine nouns of the first declension' (e.g. дэта́ляў, да́ляў, пе́чаў instead of дэта́лей, да́лей, пячэ'й; aпóвесцяў, уласці́васцяў alongside апо́весцей, уласці́васцей) ${ }^{78}$ and from Kramko, Jurevič and Janovič who regard the ending -ay̆(-яў) as a dialecticism and as such a deviation from the norm, but concede that it is acquiring a 'more or less regular character' in examples such as уласці́васцяў, рэ'чаў, дэта́ляў, плы'няў, кішэ'няў, во́сяў, да́ляў, пе́чаў. ${ }^{79} \mathrm{~A}$ recent grammar textbook rejects the ending -аў(-яў) by simply ignoring it, stating only that third declension nouns in the genitive plural have the ending -ей(-эй). ${ }^{80}$

Other scholars take a different view. Hurski points out that while the ending -ей is common to all three East Slavonic languages, in Byelorussian there is a parallel ending -ay̆(-яy̆);81 Kavalova and Sciacko state that in addition to the ending -ей(-эй) third declension nouns in the genitive plural 'often' have the ending -ay̆(-яy̆) $;^{82}$ and in Belorusskij jazyk dlja nebelorusov the authors illustrate the genitive plural of third declension nouns as follows: ${ }^{83}$

$\begin{array}{llll}\text { рэ'чаў } & \text { пячэ'й } & \text { пе́чаў } & \text { касце́й } \\ \text { да́ляў } & \text { гане́й } & \text { го́няў } & \text { гусе́й } \\ \text { ма́зяў } & \text { абласце́й } & \text { во́бласцяў } & \text { мышэй } \\ \text { чвэ'рцяў } & \text { ра́дасцей } & \text { ра́дасцяў } & \text { часцей } \\ \text { пль'няў } & \text { сенажа́цей } & \text { сенажа́цяў } & \text { крыве́й } \\ \text { скро́няў } & \text { су́вязей } & \text { су́вязяў } & \text { начэ'й }\end{array}$

76. Hramatyka biełaruskaj movy, I, p. 84.

77. Narkievič, op. cit., p. 96.

78. Laksucina, op. cit., p. 162.

79. Historyja biełaruskaj litaraturnaj movy, II, p. 300.

80. J. M. Kamaroŭski, E. S. Miacielskaja, Biełaruskaja mova. Dapamožnik

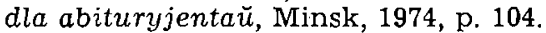

81. Hurski, op. cit., p. 116.

82. Kavalova, Sciacko, op. cit., p. 85.

33. Krivickij, Michnevič, Podlužny, op. cit., p. 85. 
In the introductory section to the third edition of their Arfainrafičny słoŭnî̀ Eoban and Sudnik also recognise the ending -ay̆(-яy̆) as a permissible alternative to -ей(-эй), but of 14 third declension nouns for which they give the genitive plural form in the vocabulary section, -яў is recommended in only one instance (капітэ'ль - капітэ'ляў) and included among the 13 for which the ending -ей(-эй) is

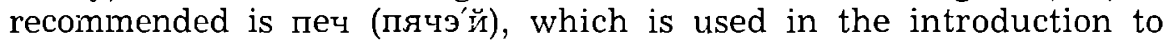
illustrate the possibility of variants (пячэ' й/пе́чаў)! ${ }^{84}$

None of the above makes any attempt to define the criteria which govern the choice of ending or the admissibility of variants. The question of whether there is a pattern to the usage of the ending -аў(-яў) was first raised by A. Kaŭrus in an article in the journal Potymia entitled Hraniaŭ ci hraniej? In this article Kaŭrus rejects the rule given by the Academy Grammar as being too simple and demonstrates that the ending -ay̆(-яy̆) is used regularly where the stress falls on the final syllable of the stem (e.g. дало́няў, ступе́няў, гра́няў) and suggests that the rule be amended to reflect this. ${ }^{85} \mathrm{~A}$ more comprehensive categorisation is given by Andrejenka and Jaŭnievič, who (echoing Kaŭrus) suggest that the ending -ay̆(-яy̆) is used if the stress falls on the last syllable of the stem, e.g. арце́ляў, дало́няў, плы'няў, рэ'чаў; and further, that -ей(-эй) is used if the noun is stressed on the ending, e.g. мышэ'й, гусе́й; and that either ending is admissible if the stress falls on any syllable of the stem other than the last, e.g. дро́бязей/дро́бязяў, апо́весцей/апо́весцяў, уласці́васцей/уласці́васцяў. Some nouns have alternative genitive plural forms with the stress in different positions and accordingly different endings, e.g. начэ'й/но́чаў, абласце́й/во́бласцяў. ${ }^{86}$

This formulation represents the first serious attempt to define the respective spheres of usage of the two endings -ей(-эй) and -аў(-яў). It proceeds from the fact of the extensive use of the latter ending in contemporary Byelorussian (something which even its most ardent opponents do not deny) and provides normative rules on this basis, whereas most other writers on this subject have taken the opposite approach and proposed rejection of the ending -ay̆(-яy̆) on the basis of such linguistically suspect criteria as desirability or tradition, in spite of the evidence of modern usage.

Andrejenka and Jaŭnievič are not without their critics. Arašonkava, for example, feels that their rules leave some questions unanswered: which ending is used by such monosyllabic nouns as даль, грань, гаць, соль еtс.? Are there nouns other than those listed (мыш, ноч, косць, гусь) which take the stressed ending -ей(-эй)? Is ноч the only noun in this group with an alternative ending -ay̆? It soon becomes clear, however, that these questions are something of a red herring, for instead of attempting to answer them Arašonkava simply uses them as a pretext to expound her own rules based on 'the written practice of many years and the traditions of the Byelorussian langu-

81. Łoban, Sudnik, op. cit., p. 37 and passim.

85. A. Kaŭrus, 'Hraniaŭ ci hraniej?', Połymia, 2, 1969, pp. 245-6.

86. U. K. Andrejenka, M. S. Jaŭnievič, Bietaruskaja mova, Minsk, 1972, p. 82. 
age, and also the lexical composition of the nouns concerned, their semantics and origin'. All this leads her to the rather unoriginal conclusion that -ей is the basic ending for the genitive plural of third declension feminine nouns; in only four words does she regard -аў(-яў) as normative (даль - да́ляў, рэч - рэ'чаў, флеш - фле́шаў, шчо́лач - шчо́лачаў) ${ }^{87}$ What is more, if one examines the questions raised (but not answered) by Arašonkava, one quickly realises that they do not constitute any real objection to Andrejenka and Jaŭnievič's formulation. To take the points seriatim: firstly, даль, грань, гаць, соль and other nouns with a monosyllabic stem are covered by the rule governing nouns with the stress on the final syllable of the stem and accordingly take the ending -яў (да́ляў, гра́няў, га́цяў, соляў); secondly, a school textbook is not normally expected to have an exhaustive list of nouns taking a particular ending, unless they constitute a small and easily definable group (Arašonkava herself does not attempt this in her own classification); and thirdly, alternative endings - with different stress - are given only for ноч (начэ' й/но́чаў) for the simple reason that of the examples quoted in that particular group it is the only one to have this characteristic.

Nevertheless, although Andrejenka and Jaŭnievič appear to have found a formula which gives an accurate picture of the situation with regard to the endings of the genitive plural of third declension nouns, it will be evident from the above that the problem is still far from being resolved in the eyes of some scholars.

\section{Instrumental plural (all declensions)}

In modern Byelorussian, as in the other East Slavonic languages, the original $a$-stem or first declension instrumental plural ending -амі(-ямі) has become generalised for all declensions. Notwithstanding this, other endings (mainly -(ь)мi, rarely -ыма) are still used by individual nouns belonging to various declensions.

The nouns involved are:

First declension

Second declension

Third declension

Heteroclitic

Pluralia tantum галава́, свіня́, сляза́

(masculine) госць, конь, цень

(neuter) кале́на, калясо́, брыво́

абро́ць, вось, дало́нь, кішэ'нь, косць

во́ка, ву́ха, плячо́

варо́ты, rро́шы, гру́дзі, дзве́ры, дзе́ці, дро́вы, лю́дзі, са́ні, се́ні

Not only in the first half of the twentieth century (as recognised by the Academy Grammar) but also in more recent times the ending -(b)Mi has been widely used in the instrumental plural of the above nouns, particularly in works of literature and, to a somewhat lesser extent, in the language of newspapers and periodicals. ${ }^{88}$ Few of these

87. Arašonkava, op. cit., pp. 78-80.

88. A. Narkievič, 'Patrebna ŭnifikacyja', Zviazda, 4 June 1965; Arašonkava, op. cit., pp. 82-3. 
forms, however, are regarded as acceptable literary forms and only one - людзьмí - is generally considered to be the sole norm. In addition to людзьмí the Academy Grammar gives literary status to the ending -(ь)мi for one other noun - дзе́цьмі (as a variant for дзе́цямі); the use of this ending in other nouns is labelled colloquial. ${ }^{89}$ Łoban and Sudnik, on the other hand, consider дзе́цьмі (like людзьмі) the sole normative form, and recognise literary variants in three instances: гру́дзі - грудзя́мі/грудзьмí, дзве́ры - дзвяра́мі/дзвярмі́, конь - ко́нямі/ко́ньмі. ${ }^{90}$

In an article in Źviazda (4 June 1965) entitled Patrebna ŭnifikacyja, A. Narkievič sought an 'improvement' in modern Byelorussian by means of the elimination of the instrumental plural endings -(b)mi, -ыма, -ымi and the establishment of a single ending -амі (-ямі) for all nouns, regardless of their gender or grammatical characteristics. He seems, however, to have found his own proposal too rigid, since he made exceptions for three nouns: людзьмí, дзяцьмí, каньмí. The last two were to be used only in a collective sense, with ,дзяцьмі, каня́мі ${ }^{11}$ as the instrumental forms where the meaning suggested individual children or horses.

Replying to Narkievič in an article published in Źviazda some months later, Kaŭrus rejected Narkievič's proposal on the grounds that a system of rules should take into account actual usage and not be based on the desires of individual linguists, ${ }^{92}$ thus showing himself to be a proponent of the descriptive rather than the prescriptive approach to language. Rather surprisingly in view of her generally normative attitude, Kaŭrus is supported in this instance by Arašonkava, albeit to a limited extent. She feels that, taking into account the extensive use of the ending -(b) mi, it should be regarded as an acceptable literary variant for the nouns гру́дзі, са́ні and сллза́. ${ }^{93}$

The instrumental plural ending -ымa, deriving from the old dual number, occurs with even less frequency than -(b)Mi and seems to be restricted to the nouns во́ка, ву́ха, плячó, гро́шы and дзве́ры (ва'чы'ма, вушы'ма, плячы'ма, грашы'ма, дзвяры'ма). It is generally regarded as a dialecticism, although frequently encountered in works of literature. Bułachaŭ, writing in 1954, was uncertain of its status but considered that it was rapidly being ousted by the generalised ending -ami, which should therefore be regarded as the literary norm, and this opinion is confirmed both by the Academy Grammar and

89. Hramatyka biełaruskaj movy, I, pp. 58, 66, 74, 84-5, 87, 89, 90, 92-3.

90. Eoban, Sudnik, op. cit., pp. 103, 108, 150.

91. There is a certain inconsistency between various sources as to the stress position in the instrumen'tal plural of дзе́ці and кóні: дзе́цямі - дзяця́мі, дзе́цьмі - дзяцьмі́, ко́нямі - каня́мі. Łoban and Sudnik, in common with the Academy Grammar, recommend stem stress in all instances.

92. A. Kaŭrus, 'Narmalizavać, ale nie źbiadniać', Źviazda, 1 Sept. 1965.

93. Arašonkava, op. cit., pp. 82-3. Other scholars also accept the instrumental plural ending -(ь)мі in the case of individual nouns: грудзьмí, слязьмі́, кале́ньмі, се́ньмі, са́ньмі, людзьмí (Kamaroŭski, Miacielskaja, op. cit., p. 105); ко́ньмі, слязьмі́, 'касцьмí (Jaŭnievič, Andrejenka, op. cit., p. 75); слязьмí, свіньмí, ко́ньмі, гасцьмі, кале́ньмі, ву́шмі, грудзьмí, касцьмí (Hurski, op. cit., pp. 102, 113, 116). 
by the relevant entries in Łoban and Sudnik's Arfahrajičny stoŭnik. ${ }^{94}$ More recent evidence, however, suggests that this may not in fact be the case. Far from becoming obsolete or being confined to the language of works of literature, the ending -bina appears to be spreading to all styles of language, and in the case of the nouns грошы and дзве́ры occurs with rather greater frequency than the ending -амі. ${ }^{95}$

94. Bułachaŭ, $A b$ niekatorych pytańniach..., p. 11; Hramatyka bietaruskaj movy, I, pp. 90, 93; Łoban, Sudnik, op. cit., pp. 94, 103, 108.

95. Arašonkava, op. cit., pp. 82-3. 